\title{
Research on Health Related Physical Fitness of Chinese Li Nationality Students
}

\author{
Jijin Sun ${ }^{1, a}$ and Yan Sheng ${ }^{1, b^{*}}$ \\ ${ }^{1}$ Qiongtai teachers college, Haikou, China \\ asjj2002033@163.com, bsj2016@163.com
}

Keywords: Health management; Fitness; Minority nationality; Education; P. E

\begin{abstract}
To study the health related physical fitness of Chinese Li nationality students of 7-18 years old, the work began with literature, survey, measurement and statistics, at last by independent samples T-test to compare the health related physical fitness of Chinese Li nationality students, there were three compare methods, first is a compare with the whole students of Li nationality, the second was concerned with the Li nationality school boys or Li nationality school girls, the third was concerned with the compare of gender. The results show that Li nationality students' health related physical fitness appears a decrease tendency in ten years, especially the pulse, the grip strength. The Li nationality school boys appear a rapid decrease than the girls, and the difference between gender changes into bigger in pulse and crook before the seat body. So, to improve the whole educational environment which surrounding these children, and to concern with their nutrition, habitation, and traditional nationality sports is the meaningful thing to do.
\end{abstract}

\section{Introduction}

From 1985, Chinese government began an investigation which about the physical fitness and health of Chinese school students, which started the next investigation per 5 years. Now begins the study with an opened data of Chinese government about physical and health research, try to learn the characteristic of Chinese Li nationality students' status of health related physical fitness.

\section{Research Objects and Methods}

Research Objects. The objects include 7-18 years old Li nationality students, which the general number is 12217 , among them, the school boy is 6315 , the school girl is 5902, and 4783 in 2005 , 7434 in 2015.

Research Methods. The main methods include literature, survey, measurement and statistics. and the measurement indexes are pulse, grip strength, and crook before the seat body etc.

In the comparison of data, the main comparison object is average level, the statistics is independent samples T-test. which the original data comes from 2005 Chinese government's opened reports of physical fitness and health research of Chinese school students or recently[1][2].

\section{Results}

Changes of Health Related Physical Fitness of Li Nationality Students from 2005 to 2015. Ten years after, Li nationality students' fitness appears decrease. Such as, the pulse, the grip strength. in ten years, the pulse increased by 4.515 time per one minute, and the grip strength decreased by $4.6943 \mathrm{~kg}$, only the crook before the seat body cannot see the obviously change. We can see clearly from the Table 1. 
Table 1 Comparison on Health Related Physical Fitness of Li Nationality Students (2005-2015)

\begin{tabular}{|c|c|c|c|c|c|c|c|c|}
\hline \multirow{3}{*}{ Index } & \multirow{3}{*}{$\begin{array}{l}\text { Equal } \\
\text { variances } \\
\text { assumed or } \\
\text { not assumed } \\
(\mathrm{Y} \text { or } \mathrm{N})\end{array}$} & \multicolumn{7}{|c|}{$\begin{array}{l}\text { Levene's Test for } \\
\text { Equality } \quad \text { oft-test for Equality of Means } \\
\text { Variances }\end{array}$} \\
\hline & & & Sig. & df & $\begin{array}{l}\text { Sig. (2 } \\
\text { tailed) }\end{array}$ & $\begin{array}{l}\text { Mean } \\
\text { Differe } \\
\text { nce }\end{array}$ & $\begin{array}{l}\text { Std. } \\
\text { Error } \\
\text { Differenc }\end{array}$ & $\begin{array}{l}95 \% \\
\text { Confidence } \\
\text { Interval of the } \\
\text { Difference }\end{array}$ \\
\hline & & & & & & & & Lower Upper \\
\hline \multirow[b]{2}{*}{ Pulse } & $\mathrm{Y}$ & 1.302 & 254 & -9.1214676 & .000 & -4.515 & .495 & $-5.485-3.544$ \\
\hline & $\mathrm{N}$ & & & $-9.138 \begin{array}{l}3442 . \\
071\end{array}$ & .000 & -4.515 & .494 & $-5.484-3.546$ \\
\hline $\begin{array}{l}\text { Grip } \\
\text { strength }\end{array}$ & Y & 699.66 & .000 & 9.8484650 & .000 & 4. 6943 & .4767 & 3.75985 .6288 \\
\hline $\begin{array}{l}\text { Crook } \\
\text { before } \\
\text { the seat } \\
\text { body }\end{array}$ & & 4. 144 & .042 & -1.7624671 & .078 & -.3281 & .1863 & -. 6933.0371 \\
\hline
\end{tabular}

Health Related Physical Fitness of Li Nationality School Boys From 2005 to 2015. For nationality school boys, the tendency of decreased is more obviously. From the Table 2, in ten years, the pulse increased by 6.122 time per minute, the grip strength decreased by $5.2936 \mathrm{~kg}$, and the crook before the seat body cannot see more change.

Table 2 Comparison on Health Related Physical Fitness of Li Nationality School Boys(2005-2015)

\begin{tabular}{|c|c|c|c|c|c|c|c|c|c|}
\hline \multirow{3}{*}{ Index } & \multirow{3}{*}{$\begin{array}{l}\text { Equal } \\
\text { variances } \\
\text { assumed or } \\
\text { not assumed } \\
(\mathrm{Y} \text { or } \mathrm{N})\end{array}$} & \multicolumn{8}{|c|}{$\begin{array}{l}\text { Levene's } \\
\text { Equality }\end{array}$} \\
\hline & & & Sig. & $\mathrm{t}$ & df & $\begin{array}{l}\text { Sig.(2- } \\
\text { tailed) }\end{array}$ & $\begin{array}{l}\text { Mean } \\
\text { Differe } \\
\text { nce }\end{array}$ & $\begin{array}{l}\text { Std. } \\
\text { Error } \\
\text { Differenc }\end{array}$ & $\begin{array}{l}95 \% \\
\text { Confidence } \\
\text { Interval of the } \\
\text { Difference }\end{array}$ \\
\hline & & & & & & & & & Lower Upper \\
\hline Pulse & $\mathrm{Y}$ & 92.804 & .000 & -6.968 & 2402 & .000 & -6.122 & .879 & $-7.845 \quad-4.400$ \\
\hline $\begin{array}{l}\text { Grip } \\
\text { strength }\end{array}$ & $\mathrm{Y}$ & 392.701 & .000 & 6.947 & 2402 & .000 & 5.2936 & .7620 & $3.7993 \quad 6.7878$ \\
\hline $\begin{array}{l}\text { Crook } \\
\text { before } \\
\text { the seat } \\
\text { body }\end{array}$ & $\mathrm{t}$ & 5.613 & .018 & .616 & 2407 & .538 & .1588 & .2577 & -.3465 \\
\hline
\end{tabular}

Changes of Health Related Physical Fitness of Li Nationality School Girls From 2005 to 2015.Perhaps the Li nationality school girls' performance are not awful than the boys. From the table 3, we can see that the pulse increased by 2.579 times per minute, and the grip strength decreased by $2.9679 \mathrm{~kg}$, but the crook before the seat body, it's obviously increased by $0.6195 \mathrm{~cm}$. 
Table 3 Comparison on Health Related Physical Fitness of Li Nationality School Girls(2005-2015)

\begin{tabular}{|c|c|c|c|c|c|c|c|c|c|}
\hline \multirow{3}{*}{ Index } & \multirow{3}{*}{$\begin{array}{c}\text { Equal } \\
\text { variances } \\
\text { assumed or } \\
\text { not assumed } \\
\text { (Y or } \mathrm{N})\end{array}$} & \multicolumn{2}{|c|}{$\begin{array}{c}\text { Levene's Test fo } \\
\text { Equality of } \\
\text { Variances }\end{array}$} & \multicolumn{6}{|c|}{ t-test for Equality of Means } \\
\hline & & \multirow[t]{2}{*}{ 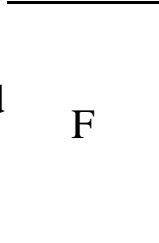 } & \multirow[t]{2}{*}{ Sig. } & \multirow[t]{2}{*}{$\mathrm{t}$} & \multirow[t]{2}{*}{ df } & \multirow[t]{2}{*}{$\begin{array}{l}\text { Sig.(2- } \\
\text { tailed) }\end{array}$} & \multirow[t]{2}{*}{$\begin{array}{l}\text { Mean } \\
\text { Differe } \\
\text { nce }\end{array}$} & \multirow[t]{2}{*}{$\begin{array}{c}\text { Std.Error } \\
\text { Differenc } \\
\text { e }\end{array}$} & $\begin{array}{c}95 \% \\
\text { Confidence } \\
\text { Interval of the } \\
\text { Difference }\end{array}$ \\
\hline & & & & & & & & & Lower Upper \\
\hline Pulse & $\mathrm{Y}$ & 221.258 & .000 & -6.620 & 2272 & .000 & -2.579 & .390 & $-3.343-1.815$ \\
\hline $\begin{array}{c}\text { Grip } \\
\text { strength }\end{array}$ & $\mathrm{Y}$ & 388.500 & .000 & 6.190 & 2246 & .000 & 2.9679 & .4795 & $2.0277 \quad 3.9082$ \\
\hline $\begin{array}{l}\text { Crook } \\
\text { before }\end{array}$ & $\mathrm{Y}$ & 1.262 & .261 & -2.380 & 2262 & .017 & -.6195 & .2602 & $-1.1298-.1091$ \\
\hline $\begin{array}{c}\text { the seat } \\
\text { body }\end{array}$ & $\mathrm{N}$ & & & -2.368 & 444.092 & .018 & -.6195 & .2616 & $-1.1326-.1063$ \\
\hline
\end{tabular}

Comparison on Health Related Physical Fitness of Li Nationality Students between Gender. When compare between gender, we can see, the difference between gender changes into bigger, except the grip strength, from $9.6346 \mathrm{~kg}$ to $7.3089 \mathrm{~kg}$. The pulse, from 3.352 time per minute to 3.7649 time per minute. And the crook before the seat body, from $1.7642 \mathrm{~cm}$ to $2.5425 \mathrm{~cm}$, they all can see obvious test significant.

Table 4 Comparison on Health Related Physical Fitness of Li Nationality Students Between Gender

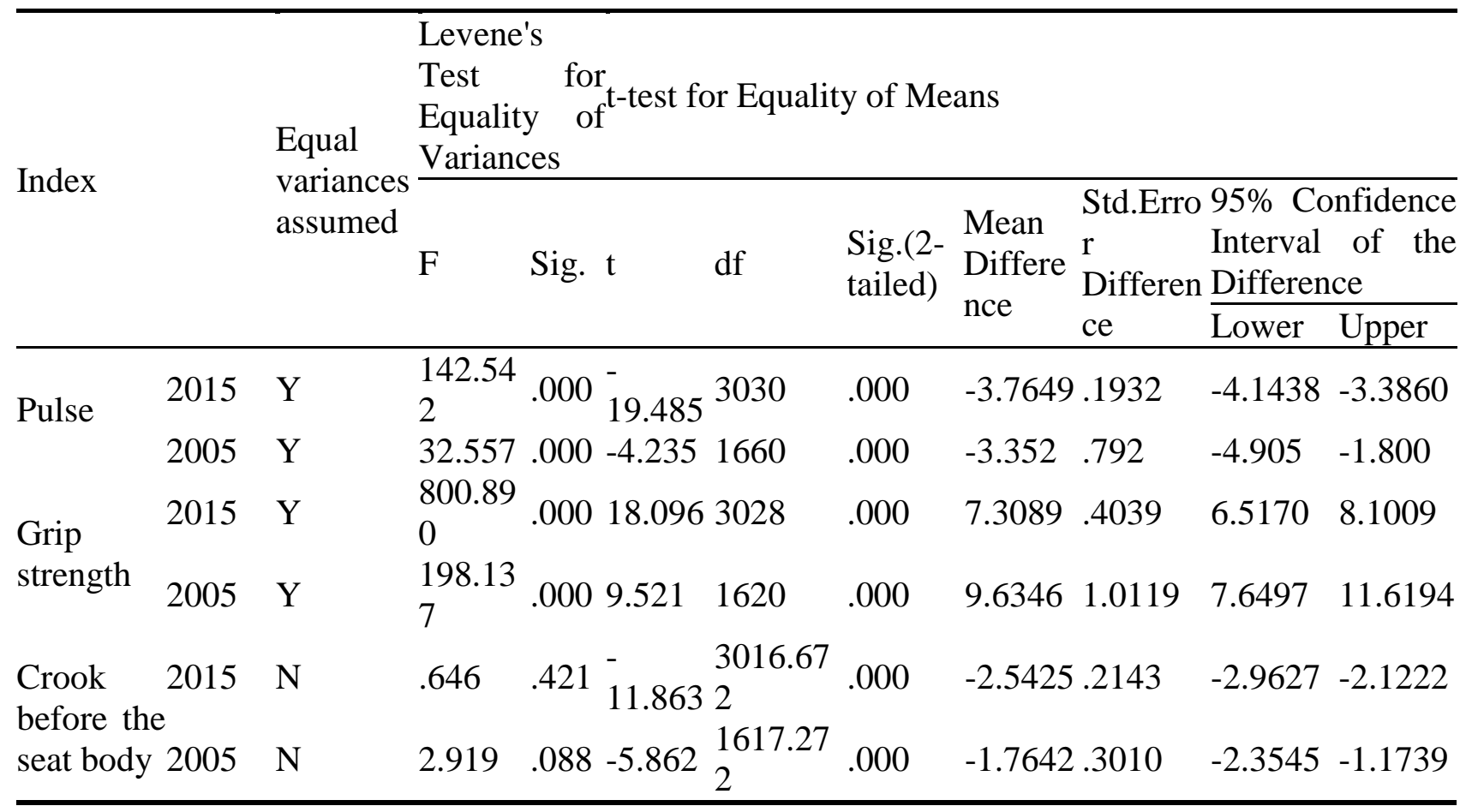

\section{Conclusion}

Li nationality students' health related physical fitness appears a decrease tendency in ten years. Especially the pulse, the grip strength. To compare with the girls, the Li nationality school boys appear a rapid decrease. Only in the crook before the seat body, only the Li nationality school girl has a silly increase. 
To compare between the genders, the difference between gender changes into bigger in pulse and crook before the seat body.

Perhaps the tendency of fitness decrease is a common phenomenon to Chinese students. So, to improve the whole educational environment which surrounding these children is the first thing to do.And to concern with the nutrition, habitation and traditional nationality sports, maybe the meaningful thing to the Li nationality students.

\section{References}

[1] Research team: 2005 Reports on the Physical Fitness and Health Research of Chinese School Students (Higher Education Press, Beijing 2007).

[2] Hao Wenting, Ni si-gui and Cai si-jie: The Research on Physical Health of Students in Hainan Province (Guangming Daily Press 2010).

[3] Zhang Hong-bin, Zhang Yan and Chen Xiao-ying: Study on nutritional status and its influence factors of children of Li nationality in Hainan province, J. Practical Preventive Medicine, Commun. 6(2006)1419.

[4] Zhang Liao, Yang Hui-qing, J. Analysis of the Somatotype of Li Teenagers in Hainan with Heath-Carter Method Contemporary Sports Technology, Commun. 4(2014)190-192.

[5] Hu Peijing, Ji Cheng-ye, Comparative Study on Physical Constitution of Rural Students Between Li and Han Nationality, J. Journal of China School Health. Commun. 26(2005)13-15.

[6] Hong Jia-yun, Comparison Analysis on Physical Fitness of Li Minority Middle and Primary School Students in Hainan Province With the Han Nationality in China, J. Fujian Sports Science and Technology, Commun. 24(2005)54-35.

[7] Zong Xue-fei, Totem and Traditional Sports of Li Nationality, J. Journal of the Central University for Nationalities, Commun. 32(2005)98-100.

[8] Jin Shan, Li minority traditional culture in social transition, J. Humanities and Social Sciences Journal of Hainan University, Commun. 27(2009)361-365.

[9] Chen Cheng, An Analysis of the Fast-developing Economy in the Li Autonomy Regions of Hainan Province in the Modern Time and the Relevant Reasons, J. Journal of Qiongzhou University, Commun. 17(2010)16-17.

[10]Xie Dong-li, Research Summary on Li nationality in China, J. Journal of Hubei University for Nationalities (Philosophy and Social Sciences), Commun. 30(2012)52-56. 